\title{
Zooplankton dynamics in mangrove and other nearshore habitats in tropical Australia*
}

\author{
A. I. Robertson, P. Dixon, P. A. Daniel \\ Australian Institute of Marine Science, PMB No. 3, Townsville MC, Queensland 4810, Australia
}

\begin{abstract}
Zooplankton was sampled in a mangrove forest, a mangrove drainage creek, the mainstream of a mangrove-dominated estuary, an adjacent seagrass flat and at an offshore $(10 \mathrm{~km})$ station in northeastern Australia every 6 wk between April 1985 and February 1986. Copepods, in particular Parvocalanus crassirostris, Paracalanus spp., several species of Oithona and Euterpina acutifrons, were numerically dominant. Community structure often differed amongst mangrove habitats, but mangrove habitats clustered separately from seagrass and bay habitats in classification analyses due to the abundance of meroplankton taxa, particularly invertebrate eggs and brachyuran zoea, in mangrove habitats. Total densities of zooplankton in mangrove and seagrass habitats (range of mean annual densities, 1.13 to $\left.1.97 \times 10^{4} \mathrm{~m}^{-3}\right)$ were always higher than in the offshore bay habitat $\left(\overline{\mathrm{x}}=0.88 \times 10^{4}\right.$ $\mathrm{m}^{-3}$ ). Mangrove and seagrass habitats exhibited marked seasonality in densities of most taxa (for total zooplankton typically ca 2 to $6 \times 10^{4} \mathrm{~m}^{-3}$ in the wet season to ca 0.1 to $5 \times 10^{3} \mathrm{~m}^{-3}$ in the dry season). Generally, seasonality in most taxa did not correlate with water temperature, salinity, mangrove litter fall or fish predation, although fish may have a significant influence on brachyuran zoea. There were often significant tidal variations in densities in mangrove creeks; low-tide densities were usually lower than high-tide values. Comparisons of the density of major prey taxa of fish in seagrass and mangrove habitats gave only partial support to the hypothesis that mangroves are more important nursery sites for zooplankton-feeding juvenile fish because they are areas of greater food abundance; during the summer recruitment period of juvenile fish, brachyuran zoea, a major prey of fish, were an order of magnitude more abundant in mangrove habitats.
\end{abstract}

\section{INTRODUCTION}

Small creeks in mangrove forests of tropical northeastern Australia harbour between 4 and 10 times the density of juvenile fish found in nearby seagrass and sandflat habitats (Robertson \& Duke 1987). The 2 most likely hypotheses which might explain such a pattern of fish densities are: (1) that there are differences in structural heterogeneity and thus the intensity of predation between habitats - the refuge hypothesis; and (2) there are differences in productivity and food availability between habitats - the food hypothesis (Robertson \& Duke 1987).

Most of the juvenile fish captured in north Queensland mangrove forests and nearby habitats are zooplankton feeders (Blaber 1980, Robertson 1987, Robertson in press [a]). How much between-habitat differences in the densities of these zooplankton-feeding

\footnotetext{
- Contribution No. 403 from the Australian Institute of Marine Science
}

fishes reflect differences in the standing stock or taxonomic composition of their prey was investigated in this study. By comparing daytime zooplankton from seagrass and mangrove habitats for a year we provide a partial test of the food hypothesis outlined above.

Previous studies of tropical, nearshore zooplankton in South East Asia (e.g. Chua 1973, Sarkar et al. 1984, Boonruang 1985) and elsewhere (e.g. Zoppi de Rao 1974, Youngbluth 1980) have been done in isolation from work on juvenile fishes. In the present study, zooplankton sampling was performed at the same sites and times of sampling juvenile fish communities (Robertson \& Duke 1987). We regularly sampled amongst the trees of mangrove forests at high tide, in small creeks draining the forests, in the mainstream of the mangrove-dominated estuary and over an adjacent seagrass flat. At irregular intervals we also sampled an offshore station to provide continuity with a previous offshore transect of Great Barrier Reef plankton abundance (Sammarco \& Crenshaw 1984). Thus, in addition to testing the above hypothesis, we also provide one of 
the most detailed analyses of zooplankton community structure in tropical, nearshore waters.

\section{METHODS AND MATERIALS}

Study site. Mangrove and seagrass habitats were sampled at Alligator Creek, near Townsville in northern Queensland, Australia (Fig. 1). Seventeen species

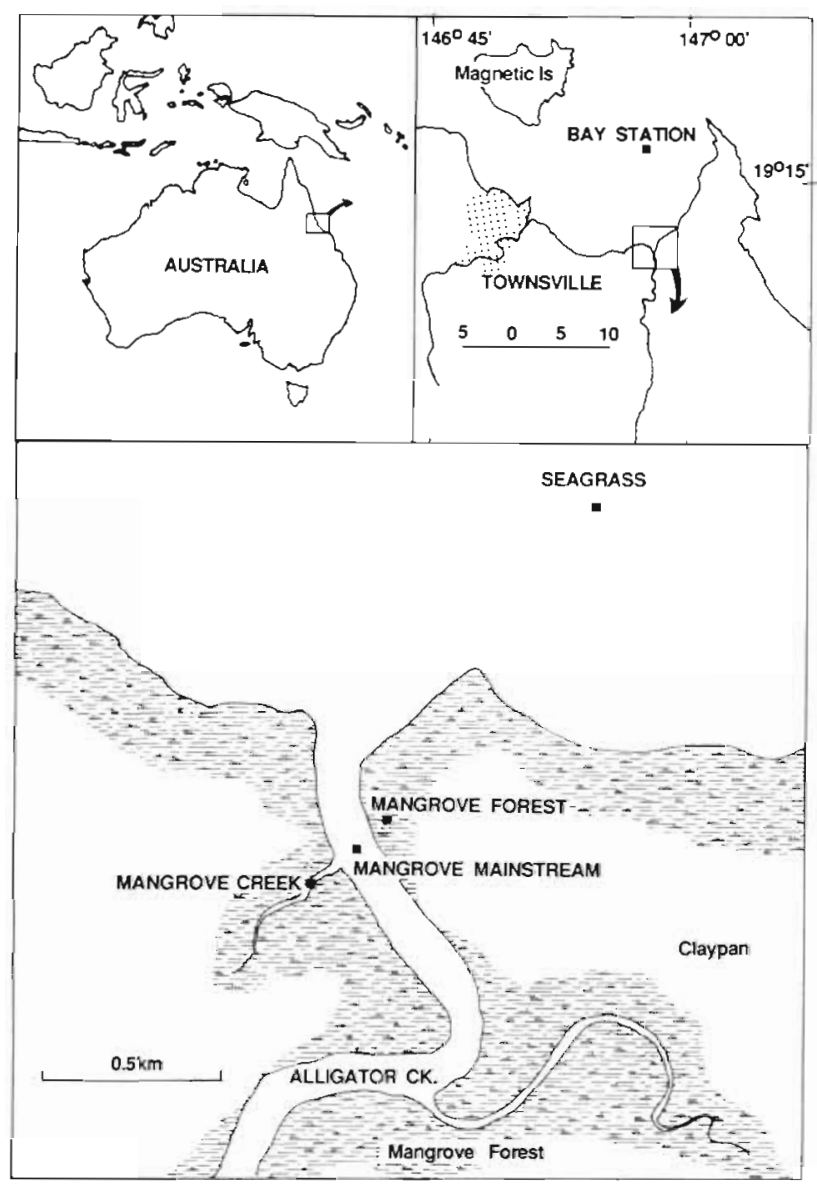

Fig. 1. Location of sampling stations

of mangrove plant have been recorded in this smail estuary ( $N$. Duke pers. comm.), but the forests are dominated by Rhizophora stylosa, Ceriops tagal and Avicennia marina. Low-tide water depth in the mainstream and smaller creeks draining the mangrove forest are $5 \mathrm{~m}$ and $0.5 \mathrm{~m}$ respectively. The maximum tidal range is ca $3.5 \mathrm{~m}$

The seagrass sampling site was $1 \mathrm{~km}$ northeast of the mouth of the estuary on the extensive mudflats that are characteristic of this region of the coast. Four seagrass species - Halophila ovalis, H. spinulosa, Halodule uninervis and Cymadocea rotundata - form patchy meadows on the mudflats. Water depths over the sea- grass sampling site ranged from 0 to $3 \mathrm{~m}$ depending on the stage of the tide.

An offshore sampling site was located $10 \mathrm{~km}$ from Alligator Creek in $10 \mathrm{~m}$ of water in Cleveland Bay (Fig. 1). Seasonal variation in mean water temperature (hand-held thermometer) and salinity (refractometer) in the mainstream of Alligator Creek and the adjacent seagrass habitat (based on measurements for $3 \mathrm{~d}$ spanning each sampling date), as well as the weekly rainfall in the catchment of Alligator Creek, are shown in Fig. 2. Also shown are temperatures and salinities on the 3 dates we sampled the offshore, bay station.

Field methods and data analysis. Between April 1985 and February 1986 zooplankton samples were taken approximately every 6 wk over the seagrass flats and in 3 habitats within the mangroves; the mainstream of Alligator Creek $1 \mathrm{~km}$ up the estuary, within a small creek draining the mangrove forest, and from within the forest itself (Fig. 1). Sampling dates were chosen as the days with the maximum predicted high tide level for each period in the year. All habitats were sampled during the day at high tide, and the mainstream and creek habitats were also sampled on the following low tide. Seagrass and forest habitats had little or no water cover at low tide.

Three times during the study high tide net samples were also taken at the offshore site. The dates - August 1985, December 1985 and February 1986 - represent respectively, the mid-dry season, the beginning of the recruitment period of post-larval fish to the estuary (Robertson \& Duke 1987), and the mid-wet season (Fig. 2).

A boat-towed net $150 \mathrm{~cm}$ diameter mouth, $105 \mu \mathrm{m}$ mesh, and fitted with a General Oceanic flow meter) was used to sample daytime zooplankton in the mangrove creek, mangrove mainstream, seagrass and bay habitats. In most cases we used 5 minute, oblique tows, beginning with the net weighted near the bottom, followed by a gradual raising of the net during the tow by shortening the tow rope. Because zooplankton in nearshore, shallow water habitats may aggregate near the bottom, or in association with some structure during the day (e.g. Robertson \& Howard 1978), oblique tows may underestimate total zooplankton densities (but see 'Discussion'). However, we used oblique tows because we required estimates of zooplankton densities across the whole water column in which the variety of fish censused by Robertson \& Duke (1987) were foraging.

In April 1985 the forest habitat was sampled by hand-hauling the net amongst the trees, but thereafter all forest samples were taken using the EZY-ZOOP pump sampler (Dixon \& Robertson 1986). This selfcontained pump system has been calibrated against net samples, and provides comparable data on taxonomic composition, total densities of zooplankton and 


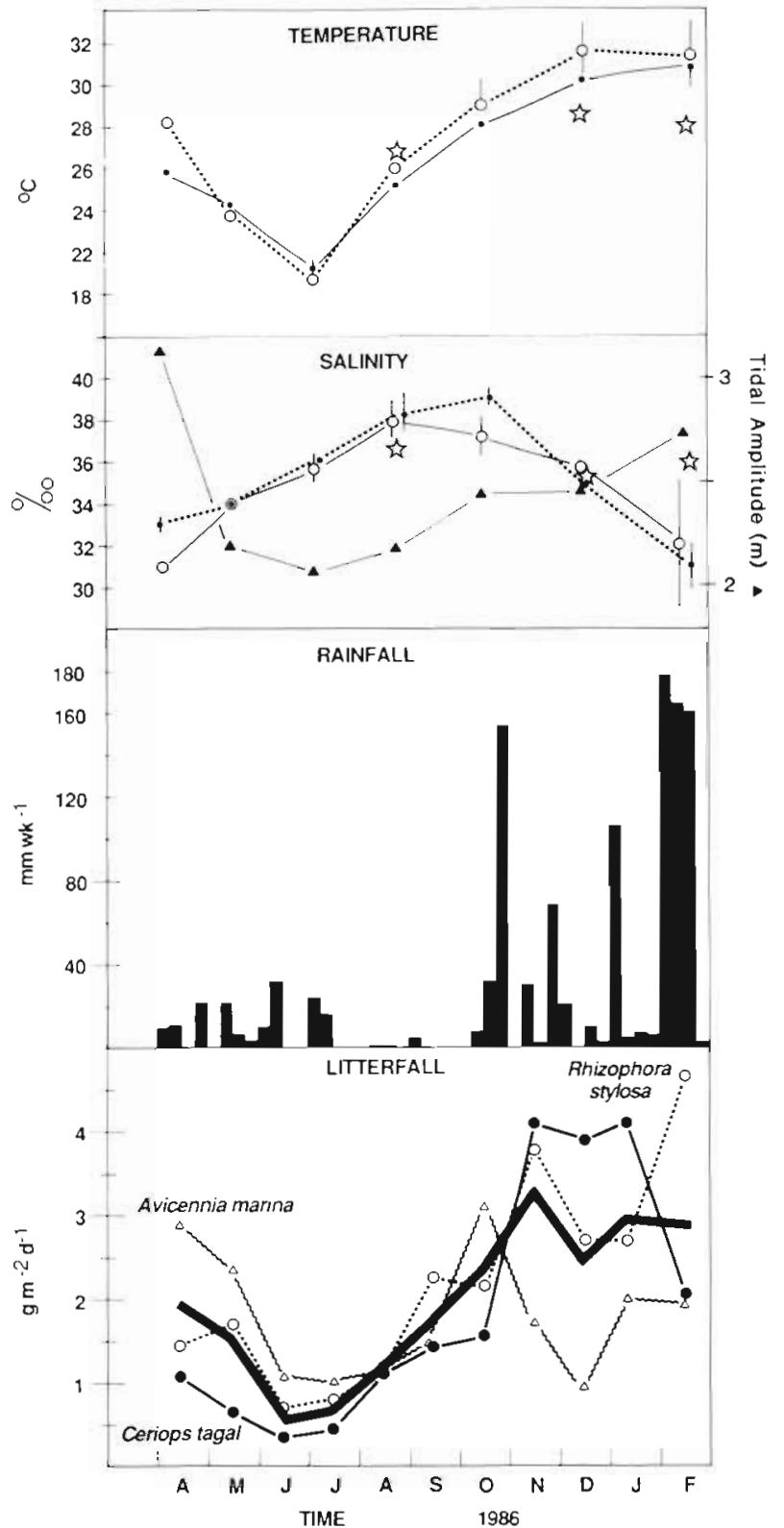

Fig. 2. Water temperature and salinity (means $\pm 1 \mathrm{SE}, n=3$ ) in seagrass $(O)$ and mangrove mainstream ( $\bullet$ habitats, predicted tidal amplitudes on sampling dates ( $\mathbf{\Delta}$ ) and rainfall in the Alligator Creek catchment during the study period. Water temperature and salinity at the bay station on the dates of sampling are also shown (c). Bottom graph: mean monthly litter fall values for the major mangrove tree species in the region and overall mean monthly litter fall (thick line)

the densities of the major taxa (copepods, nauplii and brachyuran zoea) encountered in this region (Dixon \& Robertson 1986). However, chaetognaths, polychaete larvae and larvaceans are undersampled with the pump system, while gastropod and bivalve larvae are sampled in greater densities. Statistical comparison of densities amongst all habitats are thus restricted to total catches and the 3 major taxa mentioned above.
To deploy the EZY-ZOOP system, one person swam into the forest at high tide with the sampler and then took 3 samples (each a 5 min pumping session) at randomly located sites within the forest. The intake hose was held ca $0.5 \mathrm{~m}$ below the water surface during the pumping operation. No new taxa were recorded in trials where the intake hose was held close to the trunks and prop roots of mangrove trees.

In February 1986 the water of the estuary was filled with floating debris owing to recent heavy rain (Fig. 2), precluding the use of the towed net. On this date, all samples within the estuary and over the seagrass bed were taken with the EZY-ZOOP pump. On all but one of the 7 sampling dates, 3 replicate samples were taken on each habitat/tide combination. In April 1985, the creek microhabitat was not sampled, and only one sample was taken in the seagrass habitats. Statistical comparisons of densities among habitats were therefore performed without the April data.

All samples were preserved in a $2.5 \%$ buffered formaldehyde-seawater solution in the field. In the laboratory most samples were subsampled using a Folsom plankton sample splitter. Because mangrove samples contained large amounts of plant detritus we separated zooplankton from sediment and detritus before counting commenced. The subsample to be cleaned was mixed thoroughly ( $5 \mathrm{~min}$ ) with freshwater and the silica gel Ludox, until there was 1 l of a $20 \%$ Ludox solution. This was poured into a measuring cylinder and allowed to stand for 15 to $20 \mathrm{~min}$. All sediment and most detritus collected at the bottom of the column and the rest of the solution was siphoned off and concentrated on $105 \mu \mathrm{m}$ plankton net. Several trials showed close to $100 \%$ recovery for all zooplankton and no correction factor was applied to counts. Samples were split until subsamples contained between 1000 and 2000 copepods. Relative abundance of copepod species in each sample were estimated from complete counts of the first 200 copepods in each subsample because species rarification curves on samples were asymptotic by 200 individuals.

An index of the intensity of fish predation on copepods and brachyuran zoea in the mangrove habitat was calculated for each sampling date to investigate the relationship between zooplankton abundance and fish predation. Fish biomass data were obtained from trap nettings of fish leaving the mangrove forest on ebbing tides, which were performed on the same dates used for zooplankton samples (for details of methods see Robertson in press [b]). Gut analyses were performed on fish to establish the contribution (proportion of total food volume) of copepods and zoea to the diets of fish. At least 10 individuals of the top 40 fish species, which together contributed $>95 \%$ of the total number of fish sampled during the 
study, were used for dietary analyses on each date. Full dietary data for all fish species will be published separately (Robertson unpubl.). The predation index (I) for, say, zoea at date $t$ was calculated as

$$
I_{t}=\sum_{S=1}^{S=40} B_{S} \times P_{Z}
$$

where $B_{S}=$ total biomass of fish species $S$ captured in 3 trap nettings; $P_{Z}=$ proportional representation of zoea in the fishes' diet.

Where possible, analysis of variance (ANOVA) was used to compare mean zooplankton densities. For these analyses, data were transformed $\left[\log _{10}(x+1)\right]$ and checked for homogeneity of variance $F_{\max }$ test) before analyses continued. All transformed data were homoscedastic. For several taxa ANOVA could not be used for all habitats (e.g. where all zero cells occurred or when pump and nets had differing sampling efficiency - see earlier) and comparisons were based on visual observation of data. Fortunately, in most cases, patterns were obvious and formal statistical analysis was not a problem.

Initially, high-tide density data were analysed with a 2 -way ANOVA with time of year (6 levels) and habitat (4 levels) as fixed factors. In all such comparisons there were significant interaction terms. Consequently, seasonality in each habitat, or differences among habitats at any one time, were examined using appropriate 1way ANOVAs, followed by Student-Newman-Keuls comparison of means. Tidal effects on zooplankton density were analysed using a 3-way ANOVA with tide (2 levels), time of year ( 6 levels) and habitat (2 levels) as fixed factors. If significant 3-way interactions occurred, a series of 2-way ANOVAs were performed to investigate tidal effects with habitat at any one date, or with time in any one habitat. All density data for total zooplankton, total copepods, total nauplii and brachyuran zoea were treated in this manner. Reference to significant differences between levels of a main factor in the results infers that the factor(s) has been analysed at a level where no significant interactions occurred.

All comparisons of zooplankton taxonomic composition were made using an agglomerative, hierarchical classification technique based on raw data from all replicates, with all taxa included. Bray-Curtis similarity coefficients (Bray \& Curtis 1957) were calculated between all groups, the 2 most similar groups fused to form a cluster and the process repeated using the incremental sums of squares strategy (Ward 1963).

Coefficients of second-order partial correlations (Legendre \& Legendre 1983) among the density of zooplankton taxa, water temperature, salinity and mangrove litter fall were used to investigate the possible causes of seasonality in the densities of zooplankton. In these analyses the correlation between density and one other variable was examined while the other variables were held constant, thus removing the effect of the highly significant correlations among temperature, salinity and litter fall (Legendre \& Legendre 1983). For the correlations, a lag of approximately 6 wk (the period between sampling dates) was applied to the water temperature data, because changes in density due to temperature changes probably result from a numerical response in zooplankton populations and the generation time of many of the major copepods would be ca 6 wk. Smaller lags (e.g. 4 wk) were not possible because we did not have a continuous water temperature record at Alligator Creek. Salinity was not lagged because we felt response to salinity changes would occur rapidly (e.g. Tranter \& Abraham 1971). Litter fall was chosen as an important biological variable because mangrove food chains are dependant primarily on inputs of mangrove detritus. Litter fall data from Chunda Bay, $10 \mathrm{~km}$ from Alligator Creek, were used in the analyses (N. C. Duke unpubl.). Litter fall data for the 3 major tree species at Alligator Creek are shown in Fig. 2. Because the species are approximately equally abundant at Alligator Creek, we used the mean litter fall values for all species in the analyses. Litter fall was lagged 1 mo, the period taken for significant amounts of decomposition products to become available in the water column (Robertson in press [c]). It was not appropriate to include predation by fish as a variable in the partial correlation analysis, because our index of predation was a much less precise quantity than the above 3 variables. The relationship between fish predation and zooplankton abundance was examined separately.

\section{RESULTS}

\section{Community structure}

During the sampling program, 170 taxa were recorded of which 110 were copepods. Copepods were also the numerically dominant taxa in all habitats (Table 1). Within the mangrove waterways the proportion of the total catch made up by copepods and other holoplankton differed among microhabitats. Among the meroplankton, invertebrate eggs and brachyuran zoea were more common in the forest and creek catches than in the mainstream of the estuary, while polychaete and gastropod larvae were an important component of the mainstream catch (Table 1). In the seagrass and bay catches, gastropod and bivalve larvae were the next most common taxa after copepods. Tintinnids were only recorded in large numbers in the mainstream of the mangrove habitat.

Amongst the copepods, 16 taxa predominated (Table 2). Parvocalanus crassirostris, Paracalanus spp. and several species of Oithona were abundant in all 
Table 1. Mean annual densities (no. $\mathrm{m}^{-3}$ ) of the major zooplankton taxa in each habitat. Numbers in parentheses are the total number of samples in each habitat. + : present, but $<1 \%$ of the total catch

\begin{tabular}{|c|c|c|c|c|c|}
\hline Taxon & Mainstream (42) & $\begin{array}{l}\text { Mangrove } \\
\text { Creek (39) }\end{array}$ & Forest (21) & Seagrass (19) & Bay (11) \\
\hline Copepods & 12162 & 7210 & 5024 & 14106 & 6339 \\
\hline Nauplii & 1465 & 1599 & 1031 & 751 & 288 \\
\hline Invertebrate eggs & + & 1459 & 3525 & + & + \\
\hline Brachyuran zoea & 417 & 644 & 2498 & + & + \\
\hline Tintinnids & 1993 & + & + & + & + \\
\hline Gastropod larvae & 319 & 154 & 190 & 1069 & 502 \\
\hline Bivalve larvae & + & 126 & + & 1308 & 1069 \\
\hline Polychaete larvae & 536 & + & + & 319 & + \\
\hline Larvaceans & 302 & + & + & + & 135 \\
\hline Chaetognaths & + & + & + & 365 & + \\
\hline Foraminiferans & + & + & + & 324 & + \\
\hline Echinoderm larvae & + & + & + & 235 & + \\
\hline No. other taxa & 36 & 26 & 20 & 31 & 30 \\
\hline Mean total density & 17718 & 11490 & 12718 & 19687 & 8802 \\
\hline$\%$ Holoplankton & 92.6 & 78.7 & 49.3 & 80.0 & 81.1 \\
\hline
\end{tabular}

Table 2. Mean annual densities (no. $\mathrm{m}^{-3}$ ) of the major copepods in each habitat. Numbers in parentheses are the total number of samples in each habitat. +: present but $<1 \%$ of the total catch

\begin{tabular}{|c|c|c|c|c|c|}
\hline Taxon & Mainstream (42) & $\begin{array}{l}\text { Mangrove } \\
\text { Creek (39) }\end{array}$ & Forest (21) & Seagrass (19) & Bay (11) \\
\hline Parvocalanus crassirostris & 3661 & 935 & 1469 & 2707 & 455 \\
\hline Oithona simplex & 2378 & 2627 & 1304 & 3293 & 104 \\
\hline Paracalanus 2 spp. & 1809 & 646 & 639 & 3016 & 3551 \\
\hline Oithona australis & 950 & 1022 & 510 & 668 & 143 \\
\hline Euterpina acutifrons & 910 & 333 & 341 & 870 & 144 \\
\hline Oithona nana & 551 & 267 & + & 211 & 156 \\
\hline Oithona brevicornis & 533 & 320 & + & 1329 & 741 \\
\hline Acrocalanus gracilis & 323 & + & + & 441 & 182 \\
\hline Harpacticoida & 160 & 119 & + & + & + \\
\hline Acartia baylyi & 135 & + & & + & \\
\hline Bestiola similis & 125 & + & + & + & + \\
\hline Oithona rigida & + & 284 & 155 & + & \\
\hline Oithona similis & + & 125 & + & & + \\
\hline Acartia sp. & + & 119 & & + & + \\
\hline Corycaeus catus & + & + & + & 307 & 144 \\
\hline Macrosetella gracilis & + & + & + & 216 & + \\
\hline No. other taxa & 36 & 31 & 22 & 36 & 29 \\
\hline
\end{tabular}

habitats. Between 9 and 11 copepod taxa each accounted for more than $1 \%$ of the total catch in 4 of the 5 habitats. In the mangrove forest there was a greater degree of dominance and only 6 taxa each represented greater than $1 \%$ of the total catch. Harpacticoid copepods other than Euterpina acutifrons were a significant component of the catch only in mangrove mainstream and creek samples.

Separate classification analyses for the 3 mo when all 5 habitats were sampled (high tide data) revealed that there were changes in zooplankton community structure from the bay through to the mangrove forest habitat (Fig. 3). In August 1985 mangrove forest samples were quite distinct from all others owing to the absence of most taxa except copepods in this habitat (Fig. 4), while seagrass and bay samples separated from mangrove mainstream and creek samples at a lower level of dissimilarity. In December 1985, just prior to the wet season, all bay samples and 2 of the mangrove creek samples were distinct from all other samples, and the 2 creek samples were quite dissimilar to the bay samples. At this time brachyuran zoea ranked ahead of copepods in abundance in these 2 creek samples (Fig. 4). Also, in December 2 seagrass 

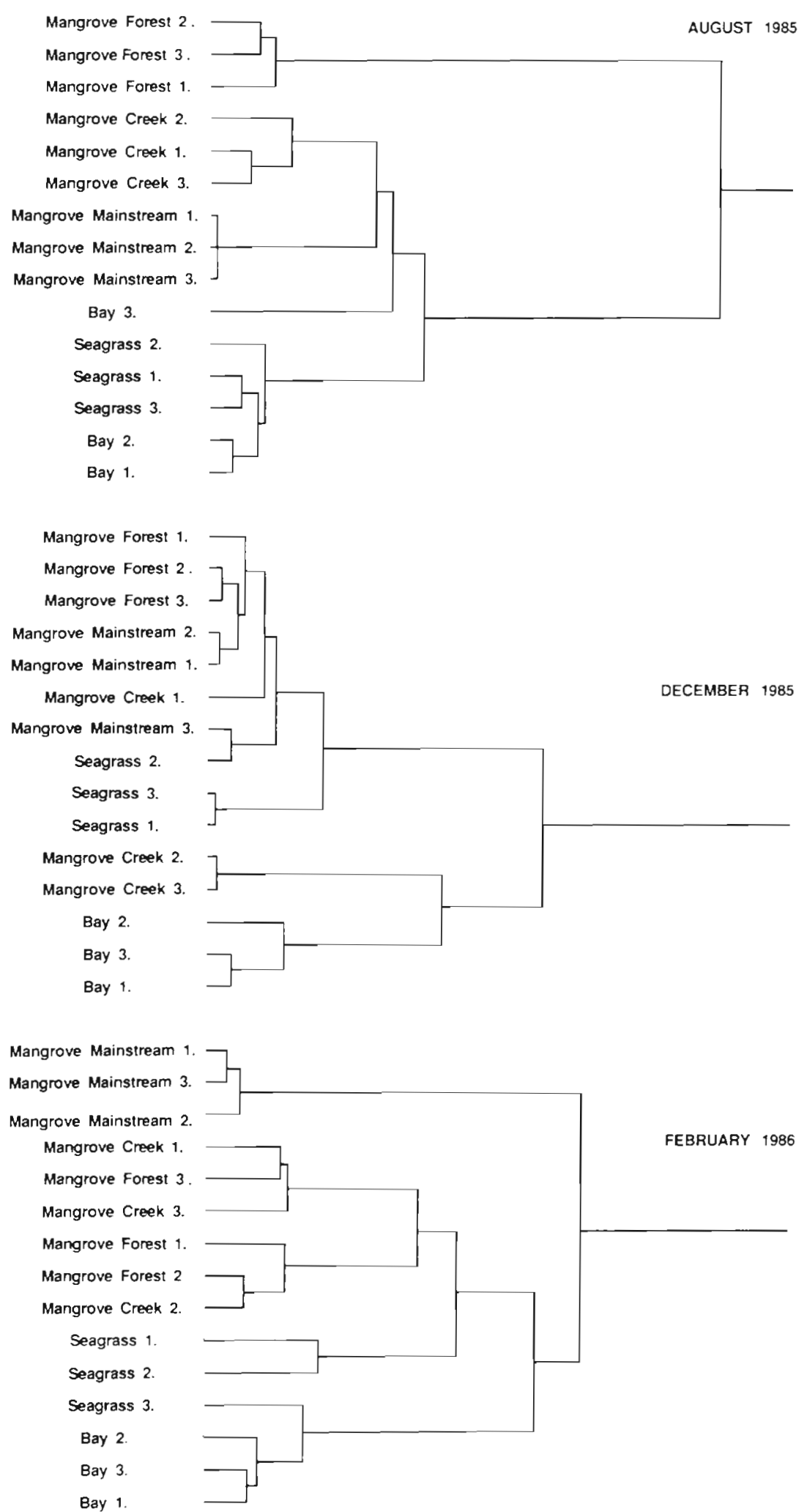

Bay 1.

Fig. 3. Dendrograms of classification analyses of community structure in replicate samples $(n=3)$ from all 5 habitats on 3 dates. Copepods were considered as 1 taxa for the classifications 


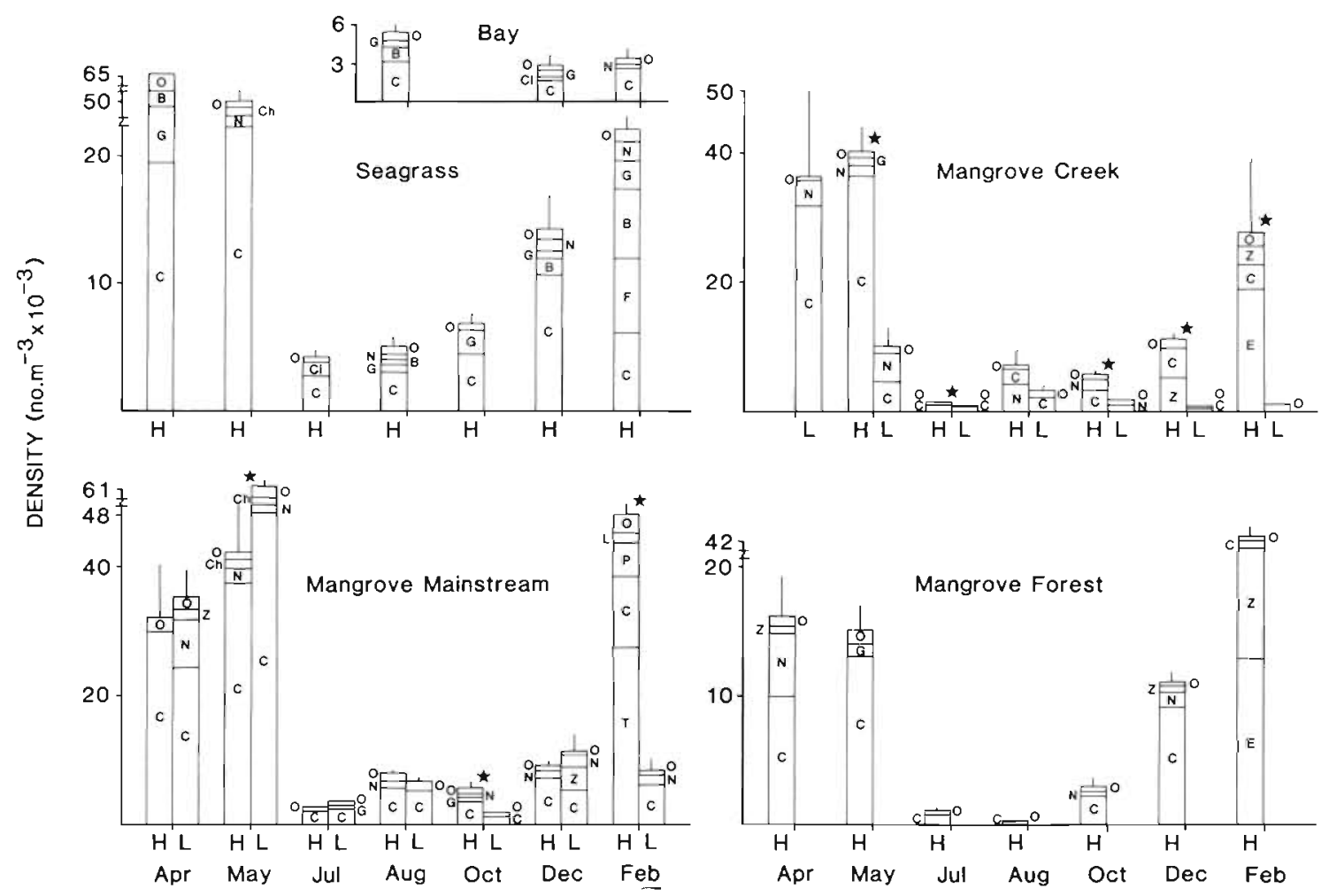

Fig. 4. Mean ( $\pm 1 \mathrm{SE}$ ) total densities (no. $\mathrm{m}^{-3}$ ) and mean taxonomic composition of zooplankton in all habitats during the study. Note changes of scale on ordinates. High tide $(\mathrm{H})$ densities are given for the bay, seagrass and forest habitats; high and low tide (L) densities for the mangrove mainstream and mangrove creek habitats (see 'Methods'). ( $\star$ ) Significant difference ( $p$ at least $<0.05$ ) between high and low tide values at any 1 date. Taxonomic composition: $\mathrm{B}$, bivalve larvae; $\mathrm{C}$, copepods; $\mathrm{Ch}$, chaetognaths; $\mathrm{Ci}$, cirripede larvae; $\mathrm{Cl}$, cladocerans; $\mathrm{E}$, invertebrate eggs; F, foraminiferans; G, gastropod larvae; L, larvaceans; N, nauplii; P, polychaete larvae; $T$, tintinnids; $Z$, brachyuran zoea; $O$, other taxa

samples were separated from all mangrove samples, but one seagrass and one mangrove mainstream sample grouped together. In contrast to the August sampling, December forest samples were similar to those from other mangrove habitats. In February 1986 all mangrove mainstream samples were quite dissimilar to other samples owing to the dominance of tintinnids in the catches (Fig. 4). All bay and seagrass samples were separated from mangrove creek and forest samples, which formed a distinct group due mainly to the abundance of invertebrate eggs and brachyuran zoea in catches (Figs. 3 and 4 ).

\section{Variation in densities}

For total zooplankton (Fig. 4), high tide densities were highly seasonal in all habitats $(p<0.001)$, with lowest mean densities occurring in the dry season months July to October and highest densities between December and May. However the ranking of habitats by density changed with season (2-way ANOVA, habitat $\times$ time interaction, $p<0.001$ ).

Comparisons of high tide mean total zooplankton densities among habitats for each sampling date (1way ANOVA's) showed that throughout the year, zooplankton densities in the seagrass habitat were equal to or greater than those in all other habitats, while mangrove mainstream and mangrove creek habitats generally harbored similar densities (Table 3; Fig. 4). From May to October densities in the mangrove forest were significantly lower than in all other habitats, but in the summer months (December and February) densities

Table 3. Results of a posteriori comparisons of mean high-tide total zooplankton densities among all habitats for each sampling date. B: Bay, S: seagrass, MM: mangrove mainstream, $\mathrm{MC}$ : mangrove creek, MF: mangrove forest

\begin{tabular}{|lr|}
\hline Month & Habitat comparisons \\
\hline May 1985. & $\mathrm{S}>\mathrm{MM}=\mathrm{MC}>\mathrm{MF}$ \\
July. & $\mathrm{S}>\mathrm{MM}=\mathrm{MC}>\mathrm{MF}$ \\
August & $\mathrm{B}=\mathrm{SM}=\mathrm{MC}>\mathrm{MF}$ \\
October & $\mathrm{S}=\mathrm{MM}=\mathrm{MC}>\mathrm{MF}$ \\
December & $\mathrm{B}<\mathrm{S}=\mathrm{MM}=\mathrm{MC}=\mathrm{MF}$ \\
February 1986 & $\mathrm{B}<\mathrm{S}=\mathrm{MM}=\mathrm{MC}=\mathrm{MF}$ \\
. Bay habitat not sampled & \\
\hline
\end{tabular}


were similar (Table 3), owing to increases in the densities of invertebrate eggs, copepods and brachyuran zoea in the forest (Fig. 4). Only in winter (August) were densities $10 \mathrm{~km}$ from shore at the bay station similar to those in the inshore habitats. However in December and February all inshore habitats had significantly $(\times 2$ to $\times 10)$ greater densities than the bay (Table 3 ; Fig. 4).

The high-tide densities of individual taxa also exhibited seasonal and between-habitat differences. Copepods were most abundant in April and May, and least abundant in July and August in all habitats. In all months except December there were significantly $(p<0.001)$ less copepods in the forest habitat than in all other habitats. Except in August and February, when it ranked second, the seagrass habitat ranked first in terms of copepod densities. In December the creek habitat contained significantly $(p<0.001)$ less copepods than all other habitats, which had equal copepod densities (Fig. 4). Brachyuran zoea were rare in all habitats between May and October, but significantly $(p<0.001)$ more zoea were present in the 3 mangrove habitats than the seagrass habitat in December and February (Fig. 4). Nauplii exhibited seasonality in the seagrass and forest habitats with lowest densities in the period July to October, while in the mainstream and creek, densities differed significantly $(p<0.001)$ among sampling dates, but there was no clear seasonality (Fig. 4). Molluscan larvae were generally more abundant over seagrass flats than in the mangrove habitats and their numbers fluctuated markedly throughout the year in all habitats (Fig. 4).

On 5 of the 6 sampling dates when comparisons were possible, low-tide, total zooplankton densities in the mangrove creek were significantly less than those at high tide, and this was also generally true for major individual taxa, e.g. copepods and brachyuran zoea, but not for nauplii (Fig. 4). The influence of tidal state on the density of total zooplankton in the mainstream habitat did not follow such a clear pattern; for instance densities were higher on the low tide in May, but the reverse was true in February (Fig. 4). Similarly, individual taxa, e.g. copepods in May and brachyuran zoea in December, were more often abundant at low tide in the mainstream habitat

Comparisons of community structure of zooplankton in mainstream and creek habitats during high and low tides revealed that on all but the 2 mid-dry season sampling dates (July, August), when tidal amplitude was lowest (Fig. 2), the community structure in creeks at high tide was very similar to community structure in the mainstream at low tide, while mainstream high tide samples and creek low tide samples were quite dissimilar (Fig. 5).
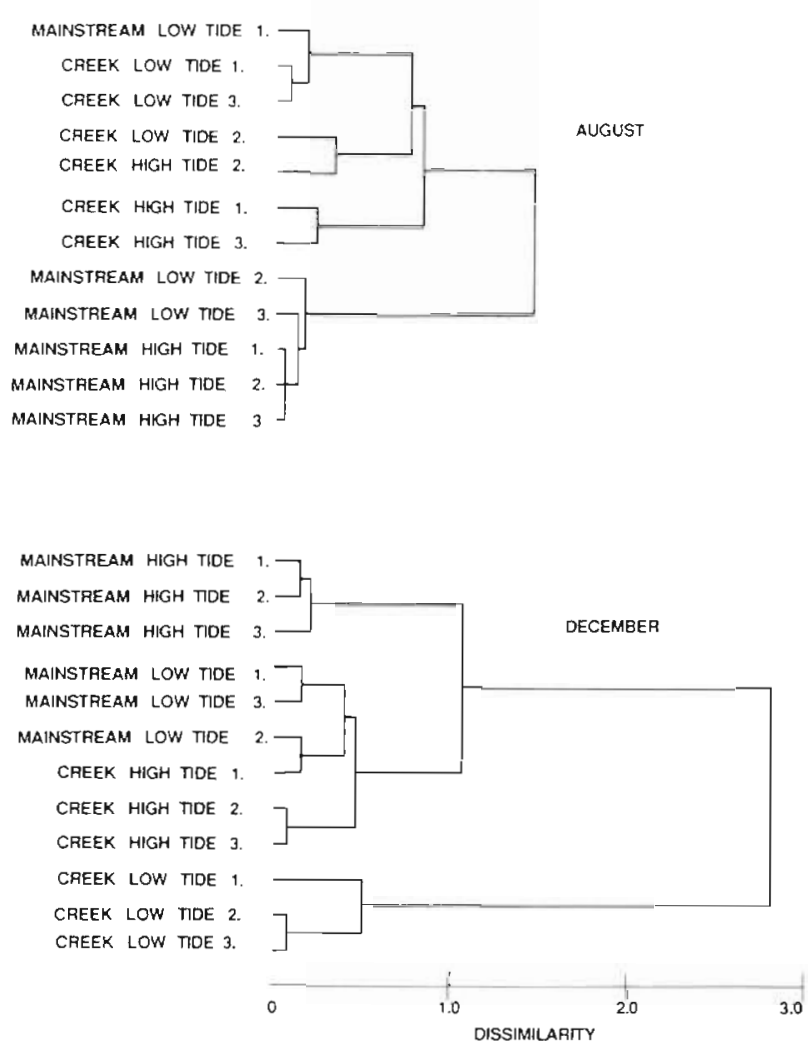

Fig. 5. Dendrograms of classification analyses of community structure in replicate samples from mangrove mainstream and creek habitats at high and low tides. Shown are typical dendrograms for July/August and October to May

In most cases, seasonal variation in the high-tide densities of most of the major 12 holo- and meroplanktonic taxa $(8$ species of copepods, brachyuran zoea and larvae of gastropods, bivalves and polychaetes) were not related to water temperature, salinity or mangrove litter fall. Significant simple correlations occurred for only 5 of the possible 36 combinations: Parvocalanus crassirostris (salinity, $r=-0.49$, $p<0.05$; litter fall, $r=0.49, p<0.05$ ), Oithona simplex (salinity, $r=-0.54, p<0.05$; litter fall, $r=0.53$, $p<0.05$ ), $O$. brevicornis (temperature, $r=-0.57$, $p<0.01$ ), zoea (temperature, $r=-0.45, p<0.05$; salinity, $r=-0.54, p<0.05$ ) and polychaete larvae (temperature, $r=0.55, p<0.05$; salinity, $r=-0.70, p<0.01$ ). However, the second-order partial correlations revealed that some of the simple correlations probably occurred because of highly significant correlation among temperature, salinity and litter fall. For instance, none of the partial correlations for $P$. crassirostris and $O$. simplex were significant. There were only 5 significant partial correlations; Paracalanus spp. with temperature $(r=-0.44, p<0.05)$, Oithona brevicornis with temperature $(r=-0.68, p<0.01)$ and litter fall $(r=0.49, p<0.05)$, and gastropod and polychaete 
larvae with salinity $(r=0.54, p<0.05$ and $r=-0.59$, $p<0.01$, respectively).

\section{Predation by fish}

Copepods and brachyuran zoea supported between 8 and $90 \%$ of the total number of juvenile fish captured in mangrove creeks, depending on the time of year (Fig. 6). Plots of the index of fish predation on these 2

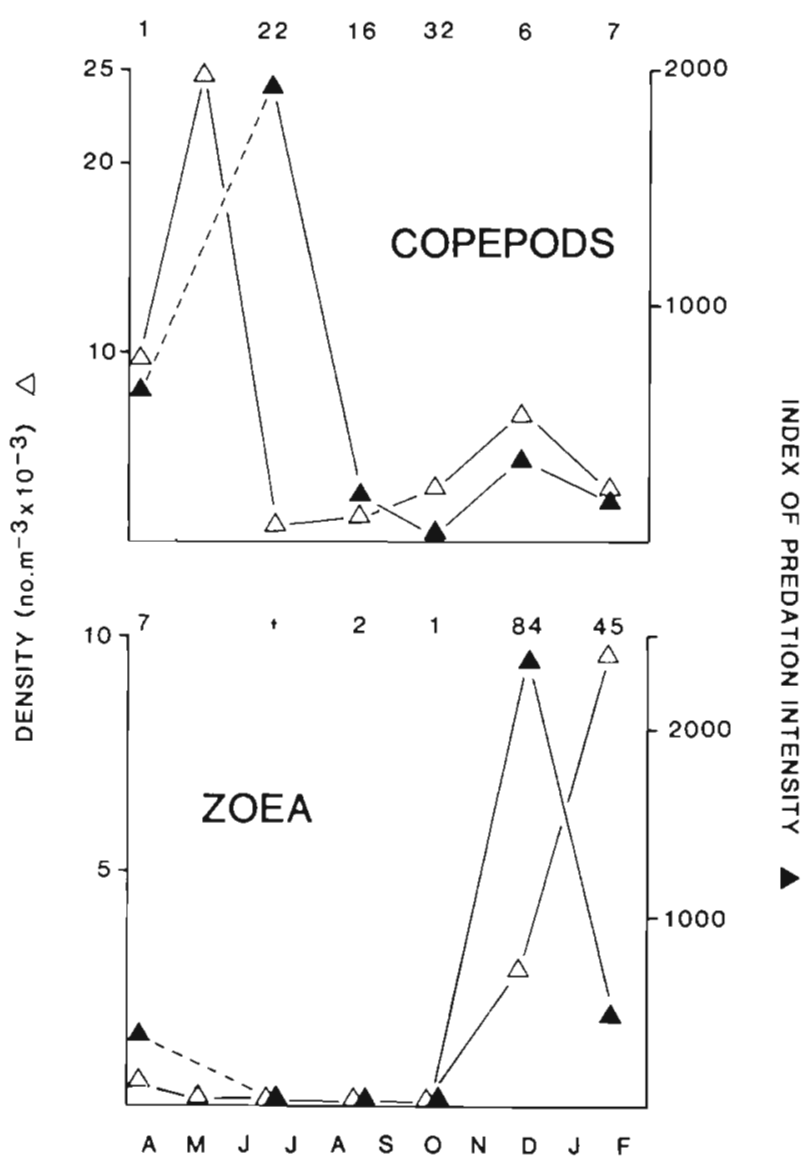

Fig. 6. Seasonal changes in mean densities of copepods and brachyuran zoea and indices of fish predation on each taxa in the mangrove creek habitat. Numbers at the top of each graph are the percentage of the total number of fish on each date estimated to be supported by copepods or zoea. Note that no fish predation data were available for the May 1985 sampling date

taxa show that predation on copepods was greatest in the dry season (July, August), while zoea were a major prey of fish in the wet season (December, February and April) (Fig. 6). The fish data on which these indices are based were collected from the forest habitat (see 'Methods'). Fish captured in trap nets had foraged both within the creek and the inundated portion of the forest during high tide, so to investigate any possible relation- ship between fish and the seasonal abundance of copepods and zoea, the predation index was plotted along with the density of copepods and zoea averaged for creek and forest habitats ( $\sum n=6$ for each date) (Fig. 6). These data reveal that it is highly unlikely that fish predation has any influence on seasonal changes in copepod densities since there is no significant relation between predation intensity and copepod abundance $\left(r_{S}=-0.74, p>0.05, n=6\right)$. In contrast, fish responded rapidly to the increased abundance of zoea in the summer, and there was a significant positive correlation between predation intensity and the mean density of zoea $\left(r_{s}=0.89, p<0.05\right.$, Fig. 6). Whether fish predation could cause significant mortality of zoea can be gauged by the following rough calculation. The mean $( \pm 1$ SE) density of zoea-feeding fish in the forest habitat in December 1985 was $2.5 \pm 0.5 \mathrm{~m}^{-3}$ and the mean $( \pm 1 \mathrm{SE})$ number of zoea per fish stomach was $281 \pm 33 \mathrm{fish}^{-1}$ (A. Robertson unpubl.). If fish had 2 (one on each tide) such meals during the day then $2.5 \times$ $281 \times 2=1405$ zoea $\mathrm{m}^{-3} \mathrm{~d}^{-1}$ would be removed, i.e. approximately half the mean density of zoea in the water column in December (Fig. 6)

\section{DISCUSSION}

\section{Spatial variation: zooplankton and juvenile fish dis- tributions}

In comparisons of the nursery ground value of mangrove forests (and associated waterways) and adjacent seagrass and mudflat habitats in North Queensland, Robertson \& Duke (1987) showed that fish were significantly more abundant in the mangrove habitat. Because the majority of such fish are zooplankton feeders (Robertson in press [a]; and see Fig. 6), the data presented in this paper can be used to test the hypothesis that quantitative or qualitative differences in zooplankton amongst inshore habitats might explain the observed differences in fish abundance.

The noticeable differences in zooplankton community structure between mangroves, seagrass and the bay habitat $10 \mathrm{~km}$ offshore in the present study reflect the results of previous studies in which sampling was performed on a transect away from shore (e.g. Coker \& Gonzalez 1960, Youngbluth 1980, Boonruang 1985). However, a striking feature of our data were the distinctions between (1) mangrove and seagrass habitats, and (2) the 3 mangrove habitats, which showed up in the classification of stations. The seagrass habitat was only $1 \mathrm{~km}$ from the entrance to the mangrove estuary, yet seagrass samples usually grouped with bay samples in the classification analyses. Among the holoplankton, copepods - in particular species of Oithona, 
Parvocalanus crassirostris, Paracalanus spp. and Euterpina acutifrons - were dominant in all habitats in the present study, as they are in many tropical and subtropical nearshore regions of the world (e.g. Coker \& Gonzalez 1960, Chua 1973, Zoppi de Rao 1974, Wooldridge 1977. Greenwood 1980, Sarkar et al. 1984, Boonruang 1985). The major reason for differences between seagrass and mangrove habitats and differences among mangrove habitats were differences in the meroplankton component of our catches. Larvae of brachyurans, gastropods, and bivalves, as well as invertebrate eggs, often made up a significant proportion of the total zooplankton in mangrove creek and forest habitats; more than $50 \%$ of the mean annual density of forest zooplankton were eggs or brachyuran zoea. This finding contrasts strongly with previous studies of tropical nearshore zooplankton (see references above), reflecting our more intensive sampling of all possible mangrove habitats, rather than truly depauperate meroplankton in other regions. We feel that the extremely high densities of brachyuran zoea may be a feature of mangrove-dominated tropical estuaries in South East Asia, because crabs of the families Grapsidae and Ocypodidae are the dominant members of the macrobenthos in that region (Macnae 1968).

Amongst the zooplankton, our results show that copepods and brachyuran zoea were the major prey of juvenile fish inhabiting mangroves during the day. Comparisons of the densities of copepods amongst habitats revealed that the seagrass habitat always harboured similar or greater densities of copepods than the 3 mangrove habitats. It thus appears unlikely that the greater density of zooplankton-feeding fish in mangrove habitats between May and August (Robertson \& Duke 1987), a period when copepods are the preferred prey of fish (see Fig. 6), can be explained by a more abundant supply of copepods in the mangrove habitats. However, during the summer (December to February) brachyuran zoea were an order of magnitude more abundant in the mangrove habitats than in the seagrass habitat. During this period brachyuran zoea were by far the most important dietary item of juvenile fish within the mangroves. Furthermore this is the main recruitment period for juvenile fish in Alligator Creek (A. Robertson unpubl.). Thus during the summer period a significant trophic benefit for juvenile fish can be derived from residence in mangrove habitats.

Several recent papers have pointed out that biases in sampling methodology may have potentially disastrous effects on testing hypotheses about the distribution and abundance of zooplankton (e.g. Hamner \& Carleton 1979, Hillmann-Kitalong \& Birkeland 1987). Our use of oblique day-time net tows to estimate the abundance of zooplankton may have led to underestimates of densities in seagrass, mainstream and creek habitats (see 'Methods'); however this is unlikely to effect conclusions reached above, for the following reasons. First, underestimating densities of total zooplankton and copepods in the seagrass habitat would only have been a problem if our data led us to reject the hypothesis of more zooplankton or copepods in mangrove versus seagrass habitats; this was not the case: our data indicates that the seagrass habitat always had equal or greater total zooplankton and copepod densities than one or both of the mangrove habitats sampled with the net. Secondly, for brachyuran zoea sampling in both seagrass and mangrove mainstream habitats would have suffered from equal bias (see 'Methods'), but in summer (December to February) significantly more brachyuran zoea were sampled in the mangrove mainstream. This indicates that our finding of significantly greater densities of zoea throughout the mangroves in summer is unlikely to be an artifact of methodology.

\section{Temporal variations in densities}

For the 8 numerically dominant copepod species in the mangrove mainstream habitat, the results of the partial correlation analyses (with temperature, salinity and litter fall), and the comparisons of copepod abundance and predation by fish, indicate our inability to explain the seasonal variance in copepod densities with any single, obvious physical or biological variable. Only Oithona brevicornis and Paracalanus spp. appear to be influenced by water temperature, and $O$. bre vicornis abundance also correlated with litter fall. The seasonal range of salinities in Alligator Creek was very small relative to other tropical estuaries in which the large changes in salinity produced by monsoonal rainfall control copepod density patterns (e.g. Tranter \& Abraham 1971, Rao 1977), and it is not surprising that in our study copepod densities did not correlate with salinity. It is likely that a combination of factors is responsible for the observed seasonality of copepods, with different factors operating together or at different times of the year to produce density fluctuation (Miller 1983). A factor which we have not considered, predation by other members of the plankton (e.g. Miller 1983), may influence copepod densities, but assessment of this factor awaits data on the specific prey of predatory groups such as the chaetognaths and ctenophores.

It is not surprising that there were few significant partial correlations between temperature, salinity, litter fall and the density of meroplankton such as brachyuran zoea and bivalve larvae. This is because seasonal changes in the densities of each of these broad taxa probably represents the responses of several species (e.g. see Fryer 1987) and that larval abundances reflect 
the reproductive output of adults and factors which influence adult population sizes. However our data indicate that predation may be implicated in decreases in the abundance of brachyuran zoea during the summer, since fish are capable of removing approximately half the standing stock of zoea per day. Such levels of predation no doubt have a significant influence on recruitment of juveniles into the crab population, and may help determine the observed abundance patterns of adult crabs in mangrove forests (Macnae 1968).

Tides can have a major influence on the structure and densities of zooplankton communities in estuaries and bays, as they did in Alligator Creek (e.g. Trinast 1975, Alldredge \& Hamner 1980). In Alligator Creek, the similarity between high-tide community structure in the creek habitat and low tide community structure in the mainstream implies that many taxa are simply flushed from the creek with the ebbing tide, to be returned on the following flood tide. Significantly, the periods when there were no tidal differences in community structure (July, August) occurred when the tidal amplitude was smallest. However because the densities of zooplankton were significantly higher in the mangrove creek at high tide than at low tide some mechanism other than simple tidal flushing must influence zooplankton abundance. The only previous study on similar blind creek habitats showed that by migrating to near the bottom of creeks, copepods accumulated in the uppermost reaches of saltmarsh creeks, rather than dispersing over the marsh with the flood tide (Jacobs 1968). On the ebb tide the copepods moved downstream, so that the densities of copepods in the uppermost region of the creek were significantly lower at low tide (Jacobs 1968). Whether such a mechanism operates for copepods in mangrove creeks awaits further work on the vertical migratory behaviour of individual copepod species. However, because we observed significantly greater high-tide densities of copepods in the mangrove forests than in the creek in December 1985, it appears unlikely that such a mechanism will explain the observed tidal variance in densities of all copepod species. This is because responses to tidal flows vary greatly among copepod species (e.g. Wooldridge \& Erasmus 1980).

Acknowledgements. P. Raffles helped with the field collections, V. Baker helped with data reduction and $\mathrm{K}$. Boto, J. Carleton, P. Rothlisberg and D. Williams and 2 anonymous referees provided helpful criticisms of earlier drafts of the paper.

\section{LITERATURE CITED}

Alldredge, A. L., Hamner, W. M. (1980). Recurring aggregation of zooplankton by a tidal current. Estuar. coast. Shelf. Sci. 10: 31-37
Blaber, S. J. M. (1980). Fish of the Trinity Inlet system of North Queensland with notes on the ecology of tropical IndoPacific estuaries. Aust. J. mar Freshwat. Res. 32: 137-146

Boonruang, P. (1985). The community structure, abundance and distribution of zooplankton at the east coast of Phuket Island, Southern Thailand, Andaman Sea. Phuket Marine Biological Center Research Bulletin No. 39

Bray, J. R., Curtis, J. T (1957). An ordination of the upland forest communities of southern Wisconsin. Ecol. Monogr $27 \cdot 325-349$

Chua Thia-Eng (1973). An ecological study of the Ponggol Estuary in Singapore. Hydrobiologia 43: 505-533

Coker, R. E., Gonzalez, J. G. (1960). Limnetic copepod populations of Bahia Fosforescente and adjacent waters, Puerto Rico. J. Elisha Mitchell Sci. Soc. 76: 8-28

Dixon, P., Robertson, A. I. (1986). A compact, self-contained zooplankton pump for use in shallow coastal habitats: design and performance compared to net samples. Mar Ecol. Prog. Ser. 32: 97-100

Fryer, G. (1987). Quantitative and qualitative: numbers and reality in the study of living organisms. Freshwat. Biol. 17: $177-189$

Greenwood, J. G. (1980). Composition and seasonal variations of zooplankton populations in Moreton Bay, Queensland. Proc. R. Soc. Queensl, 91: 85-105

Hamner, W. M., Carleton, J. H. (1979). Copepod swarms: attributes and role in coral reef ecosystems. Limnol. Oceanogr. 245: 1-14

Hillman-Kitalong, A., Birkeland, C. (1987). Comparative biases from pushnet and pullnet zooplankton samples. Mar. Ecol. Prog. Ser. 38: 131-135

Jacobs, J. (1968). Animal behaviour and water movement as codeterminants of plankton distribution in a tidal system. Sarsia 34: 355-370

Legendre, L., Legendre, P. (1983). Numerical ecology. Elsevier, Amsterdam

Macnae, W. (1968). A general account of the fauna and flora of mangrove swamps and forests in the Indo-West-Pacific region. Adv. mar. Biol. 6: 73-270

Miller, C. B. (1983). The zooplankton of estuaries. In: Ketchum, B. H. (ed.) Ecosystems of the world. 26. Estuaries and enclosed seas. Elsevier, Amsterdam, p. 103-149

Rao, T. S. S. (1977). Salinity and distribution of brackish warm water zooplankton in Indian estuaries. In: Proceedings of the symposium on warm water zooplankton. National Institute of Oceanography, Goa, India, p. 196-204

Robertson, A. I. (1987). The determination of trophic relationships in mangrove-dominated systems: areas of darkness. In: Field, C. D., Dartnall, A. J. (eds.) Mangrove ecosystems of Asia and the Pacific: status, exploitation and management. AIMS and Australian Committee for mangrove research, Townsville, p. 292-304

Robertson, A. I. (in press a). Preliminary analysis of mangrove food chains in tropical Australia. In: Harris, R. N. (ed.) The Indo-Pacific convergence. IOC Workshop Series Report IOC-Westpac, Canberra

Robertson, A. I. (in press b). Abundance, diet and predators of juvenile banana prawns, Penaeus merguiensis, in a mangrove estuary in tropical N.E. Queensland. Aust. J. mar. Freshwat. Res.

Robertson, A. I. (in press [c]). Decomposition of mangrove leaf litter in tropical Australia. J. exp. mar. Biol. Ecol.

Robertson, A. I., Duke, N. C. (1987). Mangroves as nursery sites: comparisons of the abundance and species composition of fish and crustaceans in mangroves and other nearshore habitats in tropical Australia. Mar. Biol. 96: 193-205

Robertson, A. I., Howard, R. K. (1978). Diel trophic interactions 
between vertically migrating zooplankton and their fish predators in an eelgrass community. Mar. Biol. 48: $207-213$

Sammarco, P. W., Crenshaw, H. (1984). Plankton community dynamics of the central Great Barrier Reef Lagoon: analysis of data from Ikeda et al. Mar. Biol. 82: 167-180

Sarkar, S., Baidya, A., Bhunia, A., Choudury, A. (1984). Zooplankton studies in the Hooghly estuary around Sagar Isiand, Sunderbans, India. In: Soepadmo, E., Rao, A. N., Macintosh, D. J. (eds.) Proc. Asian Symp. Mangrove. Env. Res. and Manag. Univ. of Malaya, Kuala Lumpur, p. 286-297

Tranter, D. J., Abraham, S. (1971). Coexistence of species of Acartidae (Copepoda) in the Cochin Backwater, a monsoonal estuarine lagoon. Mar. Biol. 11: 222-241

Trinast, E. M. (1975). Tidal currents and Acartia distribution in
Newport Bay, California. Estuar. coast. mar. Sci. 3: 165-176 Ward, J. H. (1963). Hierarchical grouping to optimize an objective function. J. Am. statist. Ass. 58: 236-244

Wooldridge, T. (1977). The zooplankton of Mgazana, a mangrove estuary in Transkei, Southern Africa. Zool. Afr. 12: 307-321

Wooldridge, T., Erasmus, T (1980) Utilization of tidal currents by estuarine tidal currents by estuarine zooplankton. Estuar. coast. mar. Sci. 11: 107-114

Youngbluth, M. J. (1980). Daily, seasonal and annual fluctuations among zooplankton populations in an unpolluted tropical embayment. Estuar. coast. Shelf Sci. 10: 265-287

Zoppi de Rao, E. (1974). Comparacion de algunas caracteristicas del plankton entre las lagunas costeros de Tacarigua y Unare, Venezuela. Bol. Inst. Oceanogr. Univ. Oriente 13: 129-146

This article was presented by Dr G. W. Thayer; it was accepted for printing on December 15, 1987 